\title{
Economics and Business
}

Volume 2, Number 1, June 2019

http://journals.ums.ac.id/index.php/mijeb

\section{THE EFFECT OF PROFESSIONAL SKEPTICISM, EXPERTISE, AUDIT FEE, AND AUDIT RISK ON AUDITOR'S OPINION WITH CLIENT PREFERENCE AS MODERATOR}

\author{
Betri and Thalia \\ Faculty of Economics and Business, Universitas Muhammadiyah Palembang \\ Jalan A. Yani 13 Ulu Palembang \\ Corresponding Author: betri.sirajuddin@gmail.com, purwita.thalia22@gmail.com@gmail.com
}

\begin{abstract}
The purposes of this study are to determine the effect of professional skepticism, expertise, audit fee, audit risk on the auditor's opinion, and to determine preference client as the moderating variable on the effect of professional skepticism, expertise, audit fee, and audit risk on the auditor's opinion. It is an empirical study on the public accountant firms and the Audit Board of the Republic of Indonesia (BPK RI) Representative Office in Palembang, South Sumatra, Indonesia. This study developed associative hypotheses and tested them. The data consisted of primary data and secondary data. The population of this research was the auditors of public accountant firms and BPK RI in Palembang. Totally, 111 respondents were involved. The techniques used for collecting the data were in-depth interviews, questionnaires, and documentation. The techniques used for analyzing the data were quantitative analysis and qualitative analysis. This study indicates that professional skepticism insignificantly affects the auditor's opinion, expertise significantly affects the auditor's opinion, audit fee significantly affects the auditor's opinion, and audit risk significantly affects the auditor's opinion. Furthermore, there is no significant relationship on the auditor's opinion from the interaction between the client preference and professional skepticism and expertise. Meanwhile, client preference is a quasi-moderator on the influence of audit fee and audit risk on the auditor's opinion.
\end{abstract}

Keywords: Professional Skepticism, Expertise, Audit Fee, Audit Risk, Client Preferences, Auditor's Opinion

\section{Introduction}

The current development of the business sectors in Indonesia has been upheld by different types of companies/legal entities in which they have significantly contributed to the national economic wheels. To preserve its continuity, the allocation of the capital into productive businesses must be carried out efficiently and it is crucial to provide reliable financial reports. Such reports will enable stakeholders to make decision regarding financial statements that convey about their relationship with the company.
In association with the stakeholders' diverse needs and interests, the audit of financial statement of an entity requires certified public accountants to express valid and accountable suggestion. To achieve this objective, public accountants mustrefer to the established standards, namely the Indonesian Professional Standards of Public Accountants (Standart Profesional Akuntan Publik-SPAP) of the Indonesian Institute of Certified Public Accountants (Ikatan Akuntan Publik IndonesiaIAPI), in carrying out their duties. Fulfillment of audit standards by auditors will affect the results 
of the audit, namely by providing accurate and precise opinion. According to Section 341 of the SPAP, the auditor is responsible for evaluating any major doubt on the entity's ability to maintain its viability in reasonable time period, not more than one year from the date of the financial statements being audited. The importance of auditor's opinion towards a company obliges the auditor to possess expertise and competency for identifying and gathering audit evidence. Moreover, an auditor should have professional skepticism.

The audit opinions issued by the auditors of public accounting firms (kantor akuntan publikKAP) and the Audit Board of the Republic of Indonesia (BPK RI) Representative Office in Palembang, South Sumatra, have been frequently questioned by some parties. In fact, in the past few years, there are many corruption, bribery, and manipulation cases that involve the members of KAP and BPK. Among the cases are those involved two public accountants, Rutlat Efendi and Muhammad Zen. Rutlat had to face license suspension for nine months through the Decree of the Minister of Finance (KMK) No. 866/ KM.1/2008 starting 15 December 2008. Alleged violation of auditing standards when conducting a general audit for the financial statement of PT Serasi Tunggal Mandiri-which actually ended on 31 December 2006, became the reason. He had to take the responsibility relating to fraud in examining facts and audit evidence of financial statements and later, having collusion with related parties. This action violates the code of professional conduct and has a significant influence on the auditor's report. Meanwhile, Muhammad Zen as the head of public accountant firm called Drs. Muhammad Zen dan Rekan was subjected to 3-month license suspension through KMK No. 896/KM.1/2008 dated 27 December 2008. The sanctions was given since he was responsible for alleged violation by giving an unqualified opinion for the financial statements of PT Pura Bhineka Mandiri for the financial year 2007, without any identified exceptions, even though it was not in compliance with generally accepted accounting principles or SPAP.

Based on the explanation of the background, this study aims to determine the effect of professional skepticism, expertise, audit fee, audit risk on the auditor's opinion, and to determine the client preference as the moderating variable on the relationship of professional skepticism, expertise, audit fee, and audit risk with the auditor's opinion.

\section{Literature Review \\ Professional Skepticism and Expertise}

Arens, Elder, Beasley, and Jusuf (2011, p. 407) argued that professional skepticism is an attitude that assumes management is dishonest nor assumes unquestioned honesty. This attitude also includes a questioning mind and a critical assessment of audit evidence.

Furthermore, auditors' expertise also influences the accuracy in providing opinions. In completing audit procedure, auditors are required to have adequate qualification as stipulated in the audit standard. Auditors must have adequate education and technical training in accounting practices and auditing techniques. In the State Finances Audit Standards (Standar Pemeriksaan Keuangan Negara-SPKN), the professional requirements for auditors are stipulated in the Auditing Standard 01 general standards relating to the requirements of the auditor's ability/expertise, the independence of auditor's organization and individuality, the implementation of professional skills during the fieldwork and reporting, and quality control over financial reporting. If the auditor has insufficient proficiency to evaluate audit evidence, the auditor's opinion will potentially mislead the stakeholders. Therefore, the expertise of an auditor is very essential in generating the auditor's opinion otherwise the opinion will be neither inaccurate nor unreliable.

\section{Audit Fee, Audit Risk, Client Preference, Auditor's Opinion}

Abdul (2015, p. 108) supported the statement that audit fee is also an important component in an assignment. Auditor certainly works to obtain appropriate earning. Mathius (2016, p. 176) explained the amount of audit fee will affect the audit supply and audit quality. The first opinion argues that larger accountant firms are likely to set higher fee due to monopolistic market tendencies. However, the implication is a decline in external audit demand and consequently, a decline in audit quality (Simunic, 1980). Yet auditors are allowed to lower audit fee in initial assignments to attract prospective clients. Messier (2006, p. 88) asserted that audit risk is the risk that arises when the auditor unintentionally modifies appropriate opinion for a financial report which contains material misstatement. Meanwhile, client preference is the 
concept regarding the client's particular desires for the results of an audit. It states that both timing and credibility of information resource are influential in decision-making. Moreover, Kotler (2009, p. 219) explicated that credibility entails the trust on the firm's integrity, competence, and benevolence.

The auditor's opinion is an opinion given by the auditor related to a company's financial statement whether it is appropriate or not. The Institute of Indonesian Accountants (Ikatan Akuntan Indonesia-IAI) (2013) states the audit report must include the opinion of the financial statements, in overall, of an assertion that if a statement is not given, specific reasons must be stated.

\section{Hypothesis Development}

a. Impact of Profesional Skepticism, Expertise, Audit Fee, and Audit Risk on Auditor's Opinion

The Indonesian Professional Standards of Public Accountants (SPAP, 2013) states that the auditor's professional skepticism is an attitude that includes a questioning mind and a critical assessment of audit evidence. Auditor's expertise is professional expertise possessed by an auditor as the outcome of her/his formal education, professional examinations and participation in training, seminars, symposiums and other activities. Attitude also includes a questioning mind and a critical assessment of audit evidence. According to Abdul (2015, p. 108), audit fee is also an important thing in auditor's assignment. Auditors certainly work to obtain appropriate earning based on their professionalism. Moreover, Abdul (2015, p. 136) also argued that audit risk occurs in the event that the auditor, without realizing it, does not properly modify the auditor's opinion on a financial statement that contains misstated materials. This statement supports previous research conducted by Sukendra, Yuniarta, and Atmadja (2015), Sutrisno and Fajarwati (2014), Cresensia et al. (2014), and Suraidah (2005) which showed that professional skepticism, expertise, and audit risk affected the accuracy of the auditor's opinion. Furthermore, the variable of audit fee is also presumed to affect the auditor's opinion. Based on the description, the hypothesis is formulated as follows:

H1: Professional skepticism, expertise, audit fee, and audit risk simultaneously affect the auditor's opinion.

\section{b. Impact of Auditor's Profesional Skepticism on the Auditor's Opinion}

The Indonesian Professional Standards of Public Accountants (SPAP, 2013) states that the auditor's professional skepticism is an attitude that includes a questioning mind and a critical assessment of audit evidence. Excellent professional skepticism brings positive influence on the appropriateness of the auditor's opinion. Accordingly, the results of audit on a financial statement will be more reliable for the decisionmakers of both internal and external parties. Research by Sukendra et al. (2015), Sutrisno and Fajarwati (2014), and Cresensia et al. (2014) support the positive impact of professional skepticism on the auditor's opinion. The higher the auditor's level of skepticism, the more accurate the auditor's opinion. Based on the description, the hypothesis is formulated as follows:

H2: Profesional skepticism affects the auditor's opinion.

\section{c. Impact of Auditor's Expertise on the Auditor's Opinion}

Expertise is professional expertise possessed by auditors as a result of formal education, professional examinations and participation in training, seminars, symposiums and similar activities. Sukrisno (2012, p. 32-35) argued that despite of a person's proficiency in various fields, including in the business and financial fields, she/ he cannot fulfill the requirements intended in the auditing standard if she/he does not possess educational background and experiences in auditing. Independent and professional formal education and experiences are required in which they complement each other. Research by Sukendra et al. (2015), Sutrisno and Diana Fajarwati (2014), and Cresensia et al. (2014) illustrated that the auditor's expertise has positive impact on the accuracy of the auditor's opinion. Based on the description, the hypothesis is formulated as follows:

H3: Expertise affects the auditor's opinion.

\section{d. Impact of Audit Fee on the Auditor's Opinion}

According to Abdul (2015, p. 108), audit fee is as essential as the audit assignment itself since the auditors carry out their tasks to earn appropriately. Therefore, the determination of the fee must 
be carried out by both client and auditor. For an auditor, fee is one of the objectives in completing a task thus the amount must be discussed prior to the process. Based on the expectancy theory developed by Victor H. Vroom (1964), the intensity of work effort depends on the perception than an individual's effort will result in a desired outcome. This theory implies that auditors will be more motivated to work when they have a goal, namely to earn income. In this context, income one of the objectives expected by the auditor, with all the considerations that have been made pertaining to the audit risk, thus the amount of the fee that suits the situation raises an energy to do the job better. As the result, when an auditor is enthusiast in completing a job, the performance will be better and the outcome will have good quality. It support a research conducted by Dhaliwan et al. (2008) in which audit fee affects an auditor's performance and results. Based on the description, the hypothesis is formulated as follows:

H4: Audit fee affects the auditor's opinion.

\section{e. Impact of Audit Risk on the Auditor's Opinion}

Abdul (2015, p. 136) argued that audit risk is the risk that arises when the auditor, undeliberately, does not modify appropriate opinion for a financial report which contains misstated materials. The Audit Risk and Materiality in Conducting an Audit (SAS Nos. 47 dan 82), AU 312.02, defines audit risk as the risk that the auditor may unknowingly fail to appropriately modifies his/her opinion on financial statement that is materially misstated. The acceptable audit risk has an inverse relationship with the willingness level for expressing the opinion $(90 \%)$ ) hence the audit risk is $100 \%-90 \%$. It is classified into low, moderate, or high. The standard level of audit risk is 55 , while it will not or cannot be zero. Suraidah (2005), and Gustin and Ali (2008) have argued that the audit risk affects the accuracy of the auditor's opinion. Based on this description, the hypothesis in this study is formulated as follows:

H5: Audit risk affects the auditor's opinion.

f. Effect of Profesional Skepticism, Expertise, Audit Fee, and Audit Risk on the Auditor's Opinion with Client Preference as Moderator

Client preference is a concept that occurs when the client plainly states a preferred outcome or accounting treatment, and the auditor behaves consistently with the client's preference (Haynes, 1998). This study examined, specifically, whether the auditor are persuaded by the timing of a client preference and the credibility of the client. The results reveal that client preference explicated before identification of audit evidence will direct the auditor towards the preference, and the credibility of a client who states a preference is also expected to lead the auditor to pay more attention to a preference. Therefore, client preference is predicted to affect the accuracy of the auditor's opinion. Auditor's professional skepticism is expected to influence the accuracy of the auditor's opinion as moderated by the client preference. Based on the description, the hypothesis is formulated as follows:

H6: Client preference moderates professional skepticism in affecting in affecting the auditor's opinion.

H7: Client preference moderates expertise, audit fee, and audit risk in affecting the auditor's opinion.

H8: Client preference moderates audit fee and audit risk in affecting the auditor's opinion.

H9: Client preference moderates professional skepticism, expertise, audit fee, and audit risk in affecting the auditor's opinion.

\section{Research Method}

The present study was carried out at 7 (seven) public accountant firms (KAP) and the Audit Board of the Republic of Indonesia Representative Office in Palembang, South Sumatra. The associative procedure is employed to determine the effect of association between two or more variables. The dependent variable is the auditor's opinion, the independent variables are professional skepticism, expertise, audit fee, and audit risk, while the moderator variable is client preference. The population and sample were 111 auditors selected from seven KAPs and the BPK RI Representative Office in Palembang, South Sumatra. The collected data include primary data (interviews and questionnaires) and secondary date (magazines and newspapers). The data were collected by using the Likert scale questionnaire. The analysis techniques are multiple linear analysis and moderated regression analysis (MRA). 


\section{Results and Discussion}

\section{a. Result of Questionnaire}

As many as 111 questionnaires were distributed to seven public accountant firms
(KAP) and the BPK of South Sumatra. During the collection process, 44 questionnaires were not collected by the respondents hence there were only 67 results were processed.

\section{b. Data Testing}

\section{Test Validity}

Table 1. Test Validity

\begin{tabular}{ccccccccc}
\hline $\begin{array}{c}\text { Item of } \\
\text { question }\end{array}$ & $\begin{array}{c}\mathbf{X 1} \\
\mathbf{r}_{\text {value }}\end{array}$ & $\begin{array}{c}\mathbf{X 2} \\
\mathbf{r}_{\text {value }}\end{array}$ & $\begin{array}{c}\mathbf{X 3} \\
\mathbf{r}_{\text {value }}\end{array}$ & $\begin{array}{c}\mathbf{X 4} \\
\mathbf{r}_{\text {value }}\end{array}$ & $\begin{array}{c}\mathbf{X 5} \\
\mathbf{r}_{\text {value }}\end{array}$ & $\begin{array}{c}\mathbf{Y} \\
\mathbf{r}_{\text {value }}\end{array}$ & $\mathbf{r}_{\text {table }}$ & Desc. \\
\hline 1 & 0.587 & 0.614 & 0.853 & 0.610 & 0.651 & 0.742 & 0.2404 & Valid \\
2 & 0.664 & 0.585 & 0.794 & 0.671 & 0.756 & 0.666 & 0.2404 & Valid \\
3 & 0.929 & 0.631 & 0.661 & 0.758 & 0.814 & 0.844 & 0.2404 & Valid \\
4 & 0.570 & 0.517 & 0.834 & 0.748 & 0.710 & 0.844 & 0.2404 & Valid \\
5 & 0.877 & 0.593 & 0.661 & 0.770 & 0.683 & 0.654 & 0.2404 & Valid \\
6 & 0.929 & 0.758 & & 0.805 & 0.651 & 0.886 & 0.2404 & Valid \\
7 & & & & & 0.707 & & 0.2404 & Valid \\
\hline
\end{tabular}

Source: Data, processed (2018)

Based on the results of validity testing on the items in the questionnaire, it can be claimed that all the items are valid because $r_{\text {value }}>r_{\text {table }}$ or $r_{\text {value }}$ is greater than 0.2404 .

\section{Reliability Testing}

The results of reliability testing for the variables of professional skepticism $\left(\mathrm{X}_{1}\right)$, expertise $\left(\mathrm{X}_{2}\right)$, audit fee $\left(\mathrm{X}_{3}\right)$, audit risk $\left(\mathrm{X}_{4}\right)$, client preference $\left(\mathrm{X}_{5}\right)$, and the accuracy of the auditor's opinion (Y) are indicated in the following table:

Table 2. The Result of Reliability Testing

\begin{tabular}{cccc}
\hline Variable & Cronbach's Alpha Item & $\begin{array}{c}\text { Cronbach's } \\
\text { Alpha }\end{array}$ & Description \\
\hline $\mathrm{X}_{1}$ & 0.793 & 0.6 & Reliable \\
$\mathrm{X}_{2}$ & 0.743 & 0.6 & Reliable \\
$\mathrm{X}_{3}$ & 0.794 & 0.6 & Reliable \\
$\mathrm{X}_{4}$ & 0.781 & 0.6 & Reliable \\
$\mathrm{X}_{5}$ & 0.770 & 0.6 & Reliable \\
$\mathrm{Y}$ & 0.798 & 0.6 & Reliable \\
\hline
\end{tabular}

Source: Data, processed (2018)

Based on the results of the reliability testing, the Cronbach's Alpha value of each variable is greater than the value of product moment coefficient $r$. Therefore, all items in each variable can be claimed reliable. 


\section{Normality Testing}

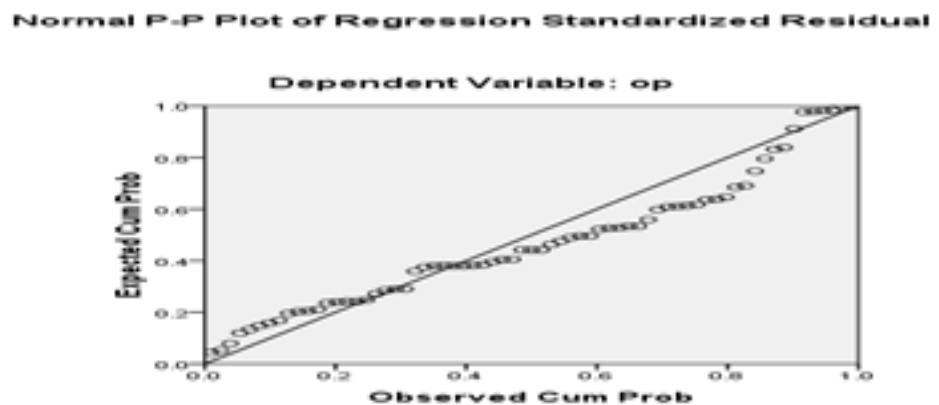

Fig. I. SPSS Test for Normality (normal P-P plot) Output

Source: The result of data processing, 2018.

Based on Fig. 1, the normal P-P plot shows the residuals conform to the diagonal normality line indicated in the plot. The assumption of normality is met hence the regression model is accurate.

\section{Multicollinearity Test}

Table 3. The Result of Multicollinearity Test

\begin{tabular}{|c|c|c|c|c|c|c|c|c|}
\hline \multicolumn{9}{|c|}{ Coefficients $^{\mathrm{a}}$} \\
\hline & \multirow[t]{2}{*}{ Model } & \multicolumn{2}{|c|}{$\begin{array}{c}\text { Unstandardized } \\
\text { Coefficients }\end{array}$} & \multirow{2}{*}{$\begin{array}{c}\begin{array}{c}\text { Standardized } \\
\text { Coefficients }\end{array} \\
\text { Beta }\end{array}$} & \multirow[b]{2}{*}{$\mathbf{t}$} & \multicolumn{3}{|c|}{ Collinearity Statistics } \\
\hline & & B & Std. Error & & & Sig. & Tolerance & VIF \\
\hline \multirow{5}{*}{1} & (Constant) & .265 & 2.463 & & .108 & .915 & & \\
\hline & $\mathrm{Sp}$ & .145 & .105 & .126 & 1.381 & .172 & .698 & 1.433 \\
\hline & $\mathrm{Kh}$ & .504 & .119 & .385 & 4.233 & .000 & .701 & 1.427 \\
\hline & $\mathrm{Fa}$ & -.363 & .100 & -.299 & -3.623 & .001 & .852 & 1.173 \\
\hline & $\mathrm{Ra}$ & .477 & .107 & .424 & 4.436 & .000 & .636 & 1.572 \\
\hline
\end{tabular}

a. Dependent Variable: op

Table IIII shows the tolerance value of each variable is greater than 0.10 while the VIF value obtained is lower than 10 hence it can be interpreted that there is no multicollinearity symptoms.

\section{Heteroscedasticity Test}

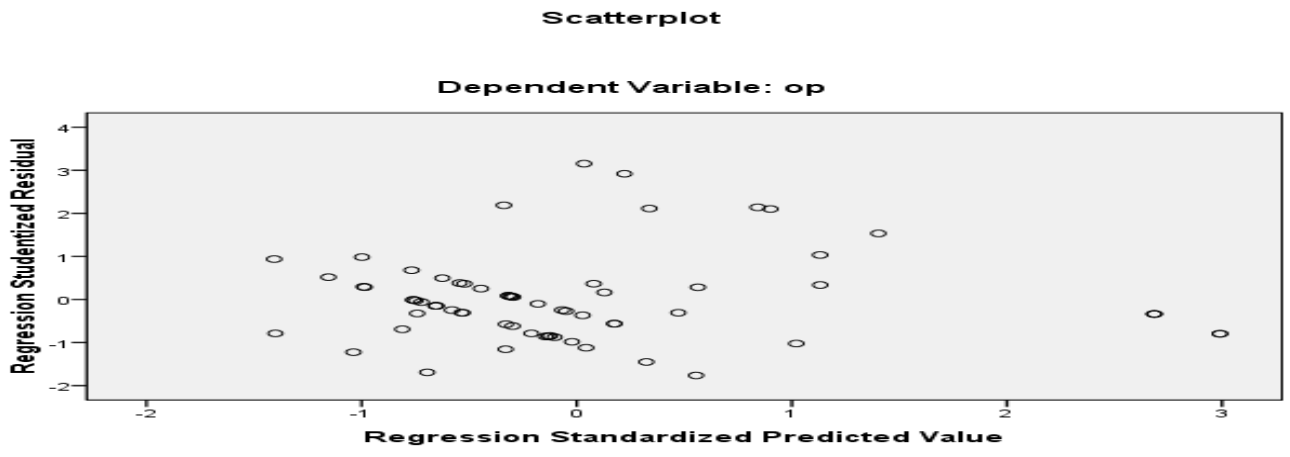

Source: Data, processed (2018)

Fig. II. SPSS Heteroscedasticity Test (Scatterplot) Output 
The result presented in Fig. II shows scatterplot graphic that illustrates there is no specific pattern between the estimated value of dependent variable and the residuals, and the points are spread above and below 0 on the $\mathrm{Y}$ axis. So, the interference is, heteroscedasticity does not present.

\section{c. Hypothesis Testing}

\section{F-Test}

H1: Professional skepticism $\left(\mathrm{X}_{1}\right)$, expertise $\left(\mathrm{X}_{2}\right)$, audit fee $\left(\mathrm{X}_{3}\right)$, audit risk $\left(\mathrm{X}_{4}\right)$ simultaneously affect the auditor's opinion (Y) thus the results are tested using the F-test as presented in Table I.

Table 4. The Result of F-Test

ANOVA $^{b}$

\begin{tabular}{rlrrrrr}
\hline & Model & Sum of Squares & Df & Mean Square & \multicolumn{1}{c}{ F } & \multicolumn{1}{c}{ Sig. } \\
\hline \multirow{4}{*}{1} & Regression & 635.073 & 4 & 158.768 & 27.534 & $.000^{\mathrm{a}}$ \\
& Residual & 357.507 & 62 & 5.766 & & \\
& Total & 992.581 & 66 & & & \\
\hline
\end{tabular}

a. Predictors: (Constant), ra, fa, kh, sp

b. Dependent Variable: op

Source: Data, processed (2018)

Table 5. The Result of F-Test

Model Summary ${ }^{b}$

\begin{tabular}{lccccc}
\hline Model & R & R Square & $\begin{array}{c}\text { Adjusted R } \\
\text { Square }\end{array}$ & $\begin{array}{c}\text { Std. Error of } \\
\text { the Estimate }\end{array}$ & Durbin-Watson \\
\hline 1 & $.800^{\mathrm{a}}$ & .640 & .617 & 2.40130 & 1.625 \\
\hline $\begin{array}{l}\text { a. Predictors: (Constant), aa, af, e, ps. } \\
\text { b. Dependent Variable: op. }\end{array}$ & & & & \\
\hline
\end{tabular}

Source: Data, processed (2018)

Hypothesis testing presented in Table IV indicates that the value of $F_{\text {ratio }}$ is 27.534 while $\mathrm{F}_{\text {table }}$ with a significance level of 0.05 and the numerator $(\mathrm{k}=4)$, so $\mathrm{k}-1=3$ and the denominator $\mathrm{df}=$ $\mathrm{n}-\mathrm{k}-1=(67-4-1)=62$ is 2.04 . In other words, $\mathrm{F}_{\text {ratio }}>\mathrm{F}_{\text {table }}(27.534>2.04)$, so it can be interpreted that professional skepticism, expertise, audit fee, and audit risk simultaneously affect the auditor's opinion. Based on the result of F-test, the $p$ value is 0.000 , or $p<$ 0.05 . It indicates the significant effect of the independent variables toward the dependent variable. So, the auditor's opinion (Y) is significantly affected by professional skepticism $\left(\mathrm{X}_{1}\right)$, expertise $\left(\mathrm{X}_{2}\right)$, audit fee $\left(\mathrm{X}_{3}\right)$, and audit risk $\left(\mathrm{X}_{4}\right)$, simultaneously.
Based on Table V, the result of hypothesis testing derived from Model Summary obtained the value of the $R$ Square $\left(R^{2}\right)$ of 0.640 , which indicates the independent variables of professional skepticism $\left(\mathrm{X}_{1}\right)$, expertise $\left(\mathrm{X}_{2}\right)$, audit fee $\left(\mathrm{X}_{3}\right)$, and audit risk $\left(\mathrm{X}_{4}\right)$ explain $64 \%$ of the dependent variable (the auditor's opinion). Meanwhile, the remaining $36 \%$ is explained by other factors excluded in the present study, i.e., experience, gender level, audit situation, ethics and other factors allegedly related to the auditor's opinion.

\section{T-Test (Partial Model)}

H2: Professional skepticism, expertise, audit fee, and audit risk partially affects the auditor's opinion. . 
Table 6. The Result of T-Test

\begin{tabular}{|c|c|c|c|c|c|c|c|c|}
\hline \multicolumn{9}{|c|}{ Coefficients $^{\mathbf{a}}$} \\
\hline & \multirow[t]{2}{*}{ Model } & \multicolumn{2}{|c|}{$\begin{array}{c}\text { Unstandardized } \\
\text { Coefficients }\end{array}$} & \multicolumn{2}{|c|}{$\begin{array}{c}\text { Standardized } \\
\text { Coefficients }\end{array}$} & \multirow[b]{2}{*}{ Sig. } & \multicolumn{2}{|c|}{$\begin{array}{c}\text { Collinearity } \\
\text { Statistics }\end{array}$} \\
\hline & & B & Std. Error & Beta & $\mathbf{T}$ & & Tolerance & VIF \\
\hline \multirow{5}{*}{1} & (Constant) & .265 & 2.463 & & .108 & .915 & & \\
\hline & Ps & .145 & .105 & .126 & 1.381 & .172 & .698 & 1.433 \\
\hline & $\mathrm{E}$ & .504 & .119 & .385 & 4.233 & .000 & .701 & 1.427 \\
\hline & Af & -.363 & .100 & -.299 & -3.623 & .001 & .852 & 1.173 \\
\hline & $\mathrm{Ar}$ & .477 & .107 & .424 & 4.436 & .000 & .636 & 1.572 \\
\hline
\end{tabular}

a. Dependent Variable: op

Source: Data, processed (2018)

The result of hypothesis testing presented in Table VI shows the value of $t_{\text {value }}$ is greater than $\mathrm{t}_{\text {table }}$ with a significance level of 0.05 and the numerator $(\mathrm{k}=4)$, so $\mathrm{k}-1=3$ and the numerator $\mathrm{df}=\mathrm{n}-\mathrm{k}-1=$ $(67-4-1)=62$ is 1.99897. In other words, $\mathrm{t}_{\text {value }}>\mathrm{t}_{\text {table }}$, so it can be interpreted that professional skepticism insignificantly affects the auditor's opinion, while expertise, audit fee, and audit risk partially affects the auditor's opinion . The $p$ value is 0.000 or $p<0.05$, so the independent variables have a significant effect on dependent variable.

\section{d. Moderated Regression Analysis (MRA)}

H3: Client preference moderates professional skepticism, expertise, audit fee, and audit risk in affecting the auditor's opinion.

Table 7. The Result of Moderated Regression Analysis (MRA) Impact of Profesional Skepticism on the Auditor's Opinion Moderated by Client Preference

Coefficients $^{\mathrm{a}}$

\begin{tabular}{ccccccc}
\hline \multirow{2}{*}{ Model } & B & \multicolumn{2}{c}{ Unstandardized Coefficients } & $\begin{array}{c}\text { Standardized } \\
\text { Coefficients }\end{array}$ & \multirow{2}{*}{ t } & \multirow{2}{*}{ Sig. } \\
\cline { 2 - 5 } & Std. Error & Beta & & & \\
\hline \multirow{2}{*}{1} & (Constant) & 5.706 & 2.807 & .033 & .046 \\
& Ps & .521 & .143 & .452 & 3.653 & .001 \\
& Cp & -.059 & .117 & -.062 & -.499 & .619 \\
\hline a. Dependent Variable: op & & & & & & \\
\hline
\end{tabular}

Source: Data, processed (2018)

Table 8. The Result of Moderated Regression Analysis (MRA) Impact of Profesional Skepticism on the Auditor's Opinion Moderated by Client Preference

\begin{tabular}{|c|c|c|c|c|c|c|}
\hline & & & oefficien & & & \\
\hline \multirow[t]{2}{*}{ Model } & \multirow[t]{2}{*}{ B } & \multicolumn{2}{|c|}{$\begin{array}{c}\text { Unstandardized } \\
\text { Coefficients }\end{array}$} & \multirow[t]{2}{*}{$\begin{array}{c}\text { Standardized } \\
\text { Coefficients } \\
\end{array}$} & \multirow[t]{2}{*}{$\mathbf{t}$} & \multirow[t]{2}{*}{ Sig. } \\
\hline & & Std. Error & Beta & & & \\
\hline \multirow{4}{*}{1} & (Constant) & 24.784 & 12.790 & & 1.938 & .057 \\
\hline & Ps & -.445 & .648 & -.386 & -.687 & .495 \\
\hline & $\mathrm{Cp}$ & -.866 & .541 & -.912 & -1.601 & .114 \\
\hline & Msp & .040 & .026 & 1.428 & 1.528 & .131 \\
\hline Denend & ariable: op & & & & & \\
\hline
\end{tabular}

Source: Data, processed (2018)

Based on Table VII, the results of the first hypothesis test between professional skepticism and client preference on the accuracy of the auditor's opinion indicate that in the first interaction, significant value of client preference is 0.619 or greater than a significance level of 0.05 . It indicates that at the first interaction, there is no significant relationship on the auditor's opinion from the interaction between client preference and professional skepticism. Furthermore, Table VIII shows the result of the second hypothesis testing for the interaction between professional skepticism, client preferences, and the interaction between professional skepticism and client preference 
on the accuracy of the auditor's opinion, with the value of msp interaction of 0.131 or greater than significance level of 0.05 . It indicates that at the second interaction, the interaction between professional skepticism and the accuracy of the auditor's opinion is insignificantly moderated by client preference.
Based on the results of the two interactions, both the first and second interactions indicate a bold insignificant moderation, so it can be claimed that the magnitude of professional skepticism towards the accuracy of the auditor's opinion is not moderated by client preference.

Table 9. The Result of Moderated Regression Analysis (MRA) Impact of Expertise on the Auditor's Opinion Moderated by Client Preference

Coefficients $^{\mathrm{a}}$

\begin{tabular}{|c|c|c|c|c|c|c|}
\hline \multirow{2}{*}{ Model } & \multirow[t]{2}{*}{ B } & \multicolumn{2}{|c|}{$\begin{array}{c}\text { Unstandardized } \\
\text { Coefficients } \\
\end{array}$} & \multirow{2}{*}{$\begin{array}{l}\text { Standardized } \\
\text { Coefficients }\end{array}$} & \multirow[t]{2}{*}{$\mathbf{t}$} & \multirow{2}{*}{ Sig. } \\
\hline & & Std. Error & Beta & & & \\
\hline \multirow{3}{*}{1} & (Constant) & -.924 & 2.588 & & -.357 & .722 \\
\hline & $\mathrm{Kh}$ & .880 & .125 & .673 & 7.058 & .000 \\
\hline & $\mathrm{Pk}$ & -.022 & .090 & -.023 & -.240 & .811 \\
\hline
\end{tabular}

a. Dependent Variable: op

Source: Data, processed (2018)

Table 10. The Result of Moderated Regression Analysis (MRA) Impact of Expertise on the Auditor's Opinion Moderated by Client Preference

Coefficients $^{\mathrm{a}}$

\begin{tabular}{|c|c|c|c|c|c|c|}
\hline \multirow[t]{2}{*}{ Model } & \multirow[t]{2}{*}{ B } & \multicolumn{2}{|c|}{$\begin{array}{c}\text { Unstandardized } \\
\text { Coefficients }\end{array}$} & \multirow[t]{2}{*}{$\begin{array}{c}\text { Standardized } \\
\text { Coefficients }\end{array}$} & \multirow[t]{2}{*}{ t } & \multirow[t]{2}{*}{ Sig. } \\
\hline & & Std. Error & Beta & & & \\
\hline \multirow{4}{*}{1} & (Constant) & -1.089 & 11.104 & & -.098 & .922 \\
\hline & $\mathrm{Kh}$ & .890 & .611 & .680 & 1.455 & .151 \\
\hline & $\mathrm{Pk}$ & -.014 & .499 & -.015 & -.029 & .977 \\
\hline & Mkh & .000 & .027 & -.012 & -.015 & .988 \\
\hline
\end{tabular}

a. Dependent Variable: op

Source: Data, processed (2018)

Based on Table IX, the first hypothesis testing on the interaction between expertise and the accuracy of the auditor's opinion moderated by client preference shows the $p$ value of client preference $(\mathrm{Cp})$ is 0.811 or $p>0.05$. It indicates that at the first interaction, expertise and the accuracy of the auditor's opinion are insignificantly moderated by client preference. Furthermore, Table X illustrates the second hypothesis for the interactions between expertise, client preferences, and the interaction of expertise moderated by client preferences on the accuracy of the auditor's opinion in which the value of $\mathrm{mkh}$ interaction of 0.988 or greater than 0.05 . It indicates that in the second interaction, expertise and the accuracy of the auditor's opinion is insignificantly moderated by client preference.

The results of the two interactions explain that both of them show that client preference does not moderate expertise towards the accuracy of the auditor's opinion. 
Betri and Thalia - The Effect of...

Table 11. The Result of Moderated Regression Analysis (MRA) Impact of Audit Fee on the Auditor's Opinion Moderated by Client Preference

\begin{tabular}{|c|c|c|c|c|c|c|}
\hline \multicolumn{7}{|c|}{ Coefficients $^{\mathrm{a}}$} \\
\hline \multirow{2}{*}{ Model } & \multirow{2}{*}{ B } & \multicolumn{2}{|c|}{$\begin{array}{l}\text { Unstandardized } \\
\text { Coefficients }\end{array}$} & \multirow{2}{*}{$\begin{array}{c}\text { Standardized } \\
\text { Coefficients }\end{array}$} & \multirow{2}{*}{$\mathbf{t}$} & \multirow{2}{*}{ Sig. } \\
\hline & & Std. Error & Beta & & & \\
\hline \multirow{3}{*}{1} & (Constant) & 14.231 & 2.357 & & 6.037 & .000 \\
\hline & $\mathrm{Fa}$ & -.560 & .166 & -.462 & -3.383 & .001 \\
\hline & $\mathrm{Pk}$ & .358 & .130 & .377 & 2.759 & .008 \\
\hline
\end{tabular}

Source: Data, processed (2018)

Table 12. The Result of Moderated Regression Analysis (MRA) Impact of Audit Fee on the Auditor's Opinion Moderated by Client Preference

\begin{tabular}{|c|c|c|c|c|c|c|}
\hline \multicolumn{7}{|c|}{ Coefficients $^{a}$} \\
\hline \multirow{2}{*}{ Model } & \multirow[t]{2}{*}{ B } & \multicolumn{2}{|c|}{$\begin{array}{c}\text { Unstandardized } \\
\text { Coefficients }\end{array}$} & \multirow{2}{*}{$\begin{array}{l}\text { Standardized } \\
\text { Coefficients }\end{array}$} & \multirow{2}{*}{$\mathbf{t}$} & \multirow{2}{*}{ Sig. } \\
\hline & & Std. Error & Beta & & & \\
\hline \multirow{4}{*}{1} & (Constant) & 20.426 & 6.713 & & 3.043 & .003 \\
\hline & $\mathrm{Fa}$ & -1.058 & .531 & -.873 & -1.991 & .051 \\
\hline & $\mathrm{Pk}$ & .016 & .370 & .017 & .043 & .966 \\
\hline & Mfa & .027 & .027 & .688 & .986 & .328 \\
\hline
\end{tabular}

Source: Data, processed (2018)

Based on Table XI, the first hypothesis testing between audit fee and the accuracy of the auditor's opinion moderated by client preference shows that in the first interaction, the $p$ value of client preference is 0.008 or $p<0.05$. It indicates that in the first interaction, client preference significantly moderates audit fees to the accuracy of the auditor's opinion. Furthermore, Table XII shows the result of the second hypothesis testing for the interaction between audit fee, client preference, and the interaction of audit fee moderated by client preference and the accuracy of the auditor's opinion in which the interaction value of mfa is 0.328 or greater than 0.05 . It indicates that in the second interaction, there is insignificant moderation of audit fee on the accuracy of the auditor's opinion moderated by client preferences.

Based on the results, in the first interaction, client preference becomes a significant moderator variable. On the contrary, in the second interaction, it becomes insignificant moderator variable. It indicates that client preference is a quasi-moderator on the effect of audit fee toward the auditor's opinion, and it corroborates the interaction between audit fee and the accuracy of the auditor's opinion as demonstrated by the positive value of the second interaction.

Table 13. The Result of Moderated Regression Analysis (MRA) Impact of Audit Risk on the Auditor's Opinion Moderated by Client Preference

\begin{tabular}{|c|c|c|c|c|c|c|}
\hline \multicolumn{7}{|c|}{ Coefficients $^{\mathrm{a}}$} \\
\hline \multirow[t]{2}{*}{ Mode } & & \multicolumn{2}{|c|}{$\begin{array}{c}\text { Unstandardized } \\
\text { Coefficients } \\
\end{array}$} & \multirow[t]{2}{*}{$\begin{array}{c}\text { Standardized } \\
\text { Coefficients } \\
\end{array}$} & \multirow[t]{2}{*}{$\mathbf{T}$} & \multirow{2}{*}{ Sig. } \\
\hline & B & Std. Error & Beta & & & \\
\hline \multirow{3}{*}{1} & (Constant) & 7.278 & 2.041 & & 3.565 & .001 \\
\hline & $\mathrm{Ra}$ & .821 & .127 & .730 & 6.442 & .000 \\
\hline & $\mathrm{Pk}$ & -.245 & .108 & -.258 & -2.276 & .026 \\
\hline
\end{tabular}

Source: Data, processed (2018) 
Table 14. The Result of Moderated Regression Analysis (MRA) Impact of Audit Risk on the Auditor's Opinion Moderated by Client Preference

\begin{tabular}{|c|c|c|c|c|c|c|}
\hline \multicolumn{7}{|c|}{ Coefficients $^{\mathrm{a}}$} \\
\hline \multirow[t]{2}{*}{ Model } & \multirow[t]{2}{*}{ B } & \multicolumn{2}{|c|}{$\begin{array}{l}\text { Unstandardized } \\
\text { Coefficients }\end{array}$} & \multirow[t]{2}{*}{$\begin{array}{c}\text { Standardized } \\
\text { Coefficients }\end{array}$} & \multirow[t]{2}{*}{$\mathbf{t}$} & \multirow[t]{2}{*}{ Sig. } \\
\hline & & Std. Error & Beta & & & \\
\hline \multirow{4}{*}{1} & (Constant) & 16.505 & 6.041 & & 2.732 & .008 \\
\hline & $\mathrm{Ra}$ & .163 & .425 & .145 & .382 & .703 \\
\hline & $\mathrm{Pk}$ & -.701 & .301 & -.738 & -2.330 & .023 \\
\hline & Mra & .032 & .020 & .944 & 1.620 & .110 \\
\hline
\end{tabular}

Source: Data, processed (2018)

Table XIII shows the result of the first hypothesis testing between audit risk and client preference on the accuracy of the auditor's opinion. In the first interaction, the $p$ value of client preference is 0.026 or $p<0.05$, which indicates client preference moderates audit risk, affecting the accuracy of the auditor's opinion significantly. Furthermore, Table XIV shows the results of the second hypothesis testing for the interaction between audit risk, client preference, and interaction of audit risk with client preferences on the accuracy of the auditor's opinion in which the value of mrs interaction is 0.110 or greater than 0.05 . It indicates that in the second interaction, the interaction between audit risk and the accuracy of the auditor's opinion is not moderated by client preference.

Analysis of the two interactions shows that in the first interaction, client preference is a significant moderator variable. Meanwhile, in the second interaction, it is an insignificant moderator variable. It confirms client preference as the moderating variable for the effect of for audit risk towards the accuracy of the auditor's opinion, and it strengthens the interaction between the two as indicated by positive mra value.

\section{e. Multiple Linear Regression Analysis}

Multiple regression analysis is carried out on the variables of professional skepticism (X1), expertise (X2), audit fee (X3), and audit risk (X4) on the auditor's opinion (Y). The equation is expressed as follows:

\section{EQUATION 1:}

$Y=a+b_{1} X_{1}+b_{2} X_{2}+b_{3} X_{3}+b_{4} X$

$Y=0.265+0.145 X_{1}+0.504 X_{2}-0.363 X_{3}+$ $0.477 \mathrm{X}_{4}$
The constant of 0.265 with positive parameters indicates that the absence of professional skepticism, expertise, audit fee and audit risk will maintain the accuracy of the auditor's opinion.

$$
\begin{aligned}
& \text { Moderated Regression Analysis } \\
& \text { EQUATION II.1: } \\
& Y=a+b_{1} X_{1}+b_{1} X_{5} \\
& Y=0.5706+0.521 X_{1}-0.059 X_{5} \\
& \text { EQUATION II.2: } \\
& Y=a+b_{1} X_{1}+b_{1} X_{5}+b_{1} X_{1} X_{5} \\
& Y=24.789-0.445 X_{1}-0.866 X_{5}+0.040 X_{1} X_{5}
\end{aligned}
$$

\section{EQUATION III.1:}

$\mathbf{Y}=\mathbf{a}+\mathbf{b}_{2} \mathbf{X}_{2}+\mathbf{b}_{2} \mathbf{X}_{5}$

$Y=\mathbf{- 0 . 9 2 4}+0.880 X_{2}-0.022 X_{5}$

\section{EQUATION III.2:}

$\mathbf{Y}=\mathbf{a}+\mathbf{b}_{2} \mathbf{X}_{5}+\mathbf{b}_{2} \mathbf{X}_{5}+\mathbf{b}_{2} \mathbf{X}_{2} \mathbf{X}_{5}$

$Y=-1.089+0.890 X_{2}-0.014 X_{5}+0.000 X_{2} X_{5}$

\section{EQUATION IV.1:}

$\mathbf{Y}=\mathbf{a}+\mathbf{b}_{3} \mathbf{X}_{3}+\mathbf{b}_{3} \mathbf{X}_{5}$

$Y=14.231-0.560 X_{3}+0.358 X_{5}$

EQUATION IV.2:

$\mathbf{Y}=\mathbf{a}+\mathbf{b}_{3} \mathbf{X}_{3}+\mathbf{b}_{3} \mathbf{X}_{5}+\mathbf{b}_{3} \mathbf{X}_{3} \mathbf{X}_{5}$

$Y=20.426-1.058 X_{3}-0.016 X_{3}+0.027 X_{3} X_{5}$

\section{EQUATION V.1:}

$\mathbf{Y}=\mathbf{a}+\mathbf{b}_{4} \mathbf{X}_{4}+\mathbf{b}_{4} \mathbf{X}_{5}$

$Y=7.278+0.821 X_{4}-0.245 X_{5}$

EQUATION V.2:

$\mathbf{Y}=\mathbf{a}+\mathbf{b}_{4} \mathbf{X}_{4}+\mathbf{b}_{4} \mathbf{X}_{5}+\mathbf{b}_{4} \mathbf{X}_{4} \mathbf{X}_{5}$

$Y=16.505+0.163 X_{4}-0.701 X_{5}+0.032 X_{4} X_{5}$

\section{Conclusion and Recommendation \\ Conclusion}

Based on the results and discussion in previous chapter, several conclusions can be 
formulated concerning the effect of professional skepticism, expertise, audit fee, and audit risk toward the auditor's opinion moderated by client preference:

1. Professional skepticism, expertise, audit fee, and audit risk simultaneously affect the accuracy of the auditor's opinion. Professional skepticism partially, insignificantly affects the auditor's opinion . Meanwhile, expertise, audit fee, and audit risk, partially and significantly affects the auditor's opinion .

2. Client preference is not significant in the effect of professional skepticism and expertise toward the auditor's opinion, while client preference is a quasi-moderator on the effect of audit fee and audit risk toward the auditor's opinion.

3.

\section{References}

Rharasati, A. I. D., \& Saputra, I. D. G. D. (2013). Faktor-faktor yang mempengaruhi auditor dalam pengambilan keputusan audit untuk memberikan opini audit. E-Jurnal Akuntansi Universitas Udayana, 3(3), 147-162. ISSN: 2302-8556.

Christiani, A. P., \& Kurnia, R. (2012). Pengaruh skeptisme profesional auditor, risiko audit, pengalaman audit, keahlian, dan independensi terhadap ketepatan pemberian opini audit. Ultima Accounting, $4(1), 22-44$.

Arens, A. A., Elder, R. J., Beasley, M. S., \& Jusuf A. A. (2011). Auditing and assurance services an integrated approach-An Indonesia adaption. (Vol. 1, 2nd ed.). (Desti Fitriani, Trans.). Jakarta: Salemba Empat.

Priyantoro, D. (2009). Mandiri belajar SPSS (3rd ed.). Jakarta: PT. Bumi Kirta.

Arum, E. D. P. (2008). Pengaruh persuasi atas preferensi klien dan pengalaman audit terhadap pertimbangan auditor dalam mengevaluasi bukti audit. Jurnal Akuntansi dan Keuangan Indonesia, $5(2)$.

Guy, M., Alderm, W. C., Winters, A. J. (2002). Auditing (Vol. 1, 5th ed.) (Sugiarto, P. A. Rajoe \& I. S. Budi). Jakarta: Erlangga.

Halim, A. (2015). Dasar-dasar audit laporan keuangan (Vol. 1, 5th ed.). Yogyakarta: Unit Penerbit dan Percetakan Sekolah Tinggi Ilmu Manajemen YKPN.

IAI Kompartemen Akuntan Publik. (2013). PSAP. Jakarta: Salemba Empat.

Suraidah, I. (2005). Pengaruh etika, kompetensi, pengalaman audit, dan resiko audit terhadap skeptisme profesional dan ketepatan pemberian opini akuntan publik. Sosiohumaniora, 7(3), 186-202.

Sukendra, I. P., Yuniarta, G. A., \& Atmadja, A. T. (2015). Pengaruh skeptisme profesional, pengalaman auditor, dan keahlian terhadap ketepatan pemberian opini oleh auditor. E-Journal S1 Akuntansi Universitas Pendidikan Ganesha, 3(1).

Prasetya, I. W. A., \& Sari, M. M. R. (2014). Pengaruh independensi, profesionalisme, dan skeptisme profesional auditor sebagai perdiktor ketepatan pemberian opini auditor. E-Jurnal Akuntansi Universitas Udayana, 9(2), 273-284. ISSN: 2302-8556.

Jawa Pos. (2017, May 27). Wow 23 pejabat BPK ternyata sudah pernah kena suap jual beli opini. 
Retrieved 30 October 2017, from (https://.jawapos.com/read/2017/05/27/132930/wow-23pejabat-bpk-ternyata-sudah-pernah-kena-suap-jual-beli-opini.Jenkins, J. G., \& Haynes, C. M. (2003). The persuasiveness of client preferences: An investigation of the Impact of preference timing and client credibility. Auditing: A Journal of Practice \& Theory, 22(1), 143 -154.

Tandiontong, M. (2016). Kualitas audit dan pengukurannya. Bandung: Penerbit Alfabeta.

Messier, W. F., Glover, S. M., \& Prawitt, D. F.. (2008). Auditing services \& assurance. (Vol 1, 4th Ed.). (Nuri Hiduan, Trans.,). Jakarta: Salemba Empat.

Mulyadi. 2013. Auditing (Vol. 1, 6th Ed, 7th Printing). Jakarta: Salemba Empat.

Pedoman Penulisan Usulan Penelitian dan Skripsi. (2017). Palembang: Lembaga Penerbit Fakultas Ekonomi dan Bisnis Universitas Muhammadiyah Palembang.

Riduan, \& Akdon. (2010). Rumus dan data dalam analisis statistika. Bandung: Alfabeta.

Priyastama, R. (2017). SPSS pengolahan data \& analisis data. Yogyakarta: Start Up.

Agoes, S. 2012. Petunjuk praktis pemeriksaan akuntan pleh akuntan publik. Jakarta: Salemba Empat.

Sugiyono. (2011). Metode penelitian kuantitatif kualitatif dan $R \& d$. Bandung: $\quad$ Alfabeta.

Sugiyono. (2013). Metode penelitian bisnis. Bandung Afabeta.

Sugiyono. (2014). Metode penelitian administrasi. Bandung: Alfabeta.

Sugiyono. (2015). Statistika untuk penelitian. Bandung: Alfabeta.

Sunjono, Setiawan, R., Carolina, V., Magdalena, N., Kurniawan, A. (2013). Aplikasi SPSS untuk Smart Riset (Program IBM SPSS 21.0). Bandung: Alfabeta.

Sutrisno, \& Fajarwati, D. (2014). Pengaruh pengalaman, keahlian, situasi audit, etika, dan gender terhadap ketepatan pemberian opini auditor melalui skeptisme profesional auditor. $J R A K, 5(2)$, $1-15$.

Pertanyakan Kinerja BPK dan BPKP Masalah Audit (2015, May 27). Retrieved 18 December 2017, from http://sumsel.tribunnews.com/amp/2015/06/29/0mbudsman-pertanyakan-kinerja-bpk-danbpkp-masalah-audit.

Sujarweni, V.W. (2015). Metodologi penelitian bisnis \& ekonomi (1st ed). Yogyakarta: Penerbit Pustaka Baru Press. 